International Research Journal of Management, IT \& Social Sciences
Available online at https://sloap.org/journals/index.php/irjmis/
Vol. 7 No. 6, November 2020, pages: 21-32
$\begin{aligned} & \text { ISSN: 2395-7492 } \\ & \text { https://doi.org/10.21744/irjmis.v7n6.997 }\end{aligned}$

\title{
Time Budget Pressure on Audit Quality with Audit Structure, Independence, and Audit Supervision as Moderating Variable
}

\author{
I Ketut Jati ${ }^{\text {a }}$ \\ Herkulanus Bambang Suprasto $^{b}$
}

Article history:

Submitted: 18 July 2020

Revised: 09 August 2020

Accepted: 27 September 2020

\section{Keywords:}

audit quality;

audit structure;

audit supervision;

independence;

time budget pressure;

\begin{abstract}
The audit quality of the public accounting firm / KAP was questioned as there were several cases of fraud, irregularity, and other unhealthy accounting practices that linked several public companies that had been audited and obtained an unqualified opinion / WTP. Empirical research shows that time budget pressure has an effect on audit quality but is not linear because moderating factors are suspected, including time budget pressure, audit structure, independence, and audit supervision. The purpose of this study was to determine the effect of time budget pressure on audit quality. The population of KAP auditors in Bali Province and the research sample was determined by purposive sampling method. The data collected were tabulated and analyzed using the Moderated Regression Analysis (MRA) technique through the following stages: classical assumption test, model feasibility test ( $F$ test), determination coefficient analysis (Ajd. R2), research hypothesis testing (ttest) for both partial and moderating effect. The results of the research show that time budget pressure has a negative effect but not statistically significant on audit quality. Furthermore, audit structure, independence, audit supervision attenuate the negative effects of time budget pressure on audit quality.
\end{abstract}

International research journal of management, IT and social sciences (C) 2020. This is an open access article under the CC BY-NC-ND license (https://creativecommons.org/licenses/by-nc-nd/4.0/).

\section{Corresponding author:}

I Ketut Jati,

Economics and Business Faculty,

Udayana University, Denpasar, Indonesia.

Email address: jatiketut@yahoo.com

\footnotetext{
Economics and Business Faculty, Udayana University, Denpasar, Indonesia

Economics and Business Faculty, Udayana University, Denpasar, Indonesia
} 


\section{Introduction}

Audit failure cases in recent decades have created a crisis of public confidence regarding the ability of the accounting profession to audit financial reports. The emergence of this crisis is reasoned because there are quite a few financial reports of a company that receives unqualified opinions, but instead face problems in the continuity of its business after the opinion is issued (Seni, 2012). The accounting manipulation scandal involving several large companies in America such as Enron, Tyco, Global Crossing, and WorldCom as well as several large companies in Indonesia such as Kimia Farma and Lippo Bank, which previously had high audit quality, led to a decline in public trust, especially the financial community (Herawaty, 2007).

The failed audit case has had a very detrimental impact in the future, such as loss of professionalism, decreased public trust and social credibility, as well as the reputation of public accountants (Hartanto, 2001; Lowensohn et al., 2007; Gul et al., 2010). Various relevant efforts to anticipate audit quality problems are urgently carried out to uncover variables that have the potential to reduce audit quality, one of which is time budget pressure.

Time budget pressure according to Dezoort (1998), is a condition that shows auditors are required to be efficient over a predetermined time, which can lead to high levels of stress and affect the attitudes, intentions, and behavior of auditors. Furthermore, Braun (2000), states that time budget pressure can be in the form of unrealistic budget planning and time estimates for the audit program that will reduce attention to the qualitative aspects of indications of misstatements that indicate the potential for fraud on financial statements. Basuki \& Mahardani (2006), emphasize that time budget pressure can reduce the quality of audit judgment either in the form of actions such as reducing examination samples or receiving weak audit evidence.

Several previous researchers have examined the effect of time budget pressure on audit quality. A study conducted by Azad (1994) found that under stressful conditions (in terms of time), auditors tended to behave dysfunctional, for example overly believing in client explanations and presentations, making premature sign-offs, and failing to investigate relevant issues. Prasita \& Adi (2007), state that time budget pressure has a negative and significant effect on audit quality. These results are in line with the research of Ningsih (2015); Kurnia (2009); Dutadasanovan (2013); and Muhshyi (2013). The study stated that the higher the time budget pressure given by the client to the auditors, it can cause a decrease in the resulting audit quality. This research contradicts research conducted by Jelista (2015); Arisinta (2013); Hapsari (2016); Willett \& Page (1996); and Aprianto (2015), which state that time budget pressure has a positive and significant effect on audit quality.

Exposure to several previous studies related to the effect of IT benefits on employee performance shows inconsistent results or is still controversial. The inconsistency of this result is presumably due to other factors that influence the relationship between the independent variable and the dependent variable. Govindarajan (1986), states that there may not be any unified research results depending on certain factors or better known as contingency factors. Murray (1990) explains that to reconcile conflicting results, a contingency approach is needed to identify other variables that act as moderators or mediators in the research model.

Several factors, both internal factors (individual characteristics of auditors) and external factors (situational factors), can act as contingency factors, including audit structure, independence, and audit supervision. These three factors are thought to be able to moderate the effect of time budget pressure on audit quality.

One of the situational factors examined in this study is the external audit structure. Bamber et al. (1989), stated that the audit structure is related to workflow coordination, authority, communication, and adaptability so that users of the audit structure approach are expected to improve auditor performance for the better. Bowrin (1998), adds that the audit structure is a systematic approach to auditing characterized by audit determination steps, logical sequence procedures, decisions, documentation, and using a comprehensive and integrated set of audit tools and policies to help auditors perform audits. . Several researchers have conducted studies on the effect of audit structure on auditor performance, for example, Eriani (2010); Hanif (2013); and Fanani et al. (2008), who found that the audit structure has a positive and significant effect on performance. The same results were found in Putra \& Dodik (2012) and Gayatri \& Suputra's (2016) research. Based on conceptual descriptions and empirical research, it can be seen that the audit structure has a positive effect on audit quality so that an auditor who is equipped with an adequate audit structure is expected to be able to condition himself to be more able to control the time budget pressures faced to achieve the desired objectives and audit quality.

Next, the situational factor that is relevant to efforts to reduce time budget pressures is independence. Mulyadi (2008), states that independence is a mental attitude that is free from influence, not controlled by other parties, not dependent on others. Independence also means the existence of honesty in an auditor in considering facts and the existence of impartial objective considerations within the auditor in formulating and expressing his opinion. Public 
accountants are not allowed to side with the interests of anyone. Public accountants are obliged to be honest not only with management and company owners but also to creditors and other parties who place their trust in the work of public accountants (Christiawan, 2002). Several researchers have tested and found a positive effect of independence on audit quality, among others: Alim et al. (2007); Putri (2013); and Kurnia et al. (2014). Based on the conceptual description and the results of empirical research, it can be seen that there is a positive effect of independence on audit quality, and it is very reasonable to predict the potential to reduce time budget pressure on audit quality.

Furthermore, another situational factor that plays a significant role in audit quality is audit supervision. Supervision is a very important element in auditing because of the large amount of work that must be done by lower-level auditors (Arens et al., 2008). Huda (2000), states that the purpose of supervision is to increase the productivity of the workforce concerned, in addition to ensuring that planning will be carried out as real. In conducting an audit, lower level auditors are assigned the task of carrying out various predefined audit procedures. For the implementation of the audit procedure as planned, there must be a party (superior) who oversees the implementation of the work performed by the auditor (Messier et al., 2006). Audit quality is largely determined by the professional performance of the audit team members (Herbach, 2001; Kirana \& Ramantha, 2020). With supervision, it is expected that the quality of work carried out by audit staff can be improved. It is very reasonable to think that it will help auditors control time budget pressures to support audit quality.

The difference between this study and previous research is the use of different objects and time dimensions (confirmatory research). This study also tries to determine the moderation ability of three contingency factors (audit structure, independence, and audit supervision) on the effect of time budget pressure on audit quality.

\section{Literature review}

Agency theory and attribution theory

Agency theory is a relationship described by Jensen \& Meckling (1976), as a contract in which the company owner is unable to manage his own company so that the company owner delegates authority to the manager to make the best decisions for the company owner. In achieving the goal of maximizing shareholder prosperity, there are often different goals between managers and company owners which will cause conflict or agency problems. To resolve this conflict, agency costs are required, namely the cost of auditing financial statements by external auditors. The auditor as an independent third party is considered capable of resolving the conflict between the principal and the agent while maintaining his independence and upholding his commitment to the organization.

Attribution theory was developed by Fritz Heider, which states that a person's behavior is determined by a combination of internal strength, which is a power that comes from within a person or is inherent in a person, for example, abilities, personal attitudes, effort and motivation, and external forces are forces that come from outside of a person, for example, social values, social conditions, difficulties at work, luck and people's views (Mindarti, 2015). Internal attributions in this study are the attitude of auditor independence and auditor commitment to the organization, while external attributions in this study are time pressure. Attribution theory states that external attributions can change a person's behavior.

\section{Contingency approach}

The contingency approach can be used to analyze the design and management of accounting systems to provide information that companies can use for a variety of purposes. This theory explains that management control can be applied to the characteristics of any company. Fisher (1998), argues that this contingency approach reveals that the planning and use of a management control system design depend on the characteristics of the organization and the environmental conditions in which the system is implemented. The contingency approach attracts the interest of researchers because they want to know whether the level of reliability of a management accounting system will always have the same effect on every condition or not. Based on the contingency approach, other situational factors may interact with each other in certain conditions. Several studies in accounting use a contingency approach to see the relationship between contextual variables (Outley, 1980), in this study the audit structure, independence, and audit supervision.

Jati , I. K., \& Suprasto , H. B. . (2020). Time budget pressure on audit quality with audit structure, independence, and audit supervision as moderating variable. International Research Journal of Management, IT and Social Sciences, 7(6). https://doi.org/10.21744/irjmis.v7n6.997 
Audit quality

Audit quality is the totality of the characteristics and characteristics of a product or service that can satisfy user needs at the right time at a reasonable price (Amin, 2000). Meanwhile, the European Supreme Audit Institution (SAI) defines audit quality as: "Quality is the degree to which a set of inherent characteristics of an audit fulfills requirements". Audit quality is a certain level where a set of audit characteristics can meet what is expected from the audit, such as a) Significance, b) Reliability, c) Objectivity, d) Scope, e) Timeliness, f) Clarity, g) Efficiency h) Effectiveness.

Mulyadi (2008), states that the performance of auditors is a public accountant who has carried out the task of examining the financial statements of a company or organization which aims to assess whether the financial statements have been presented fairly and are by generally accepted accounting principles such as material matters, positions finance and the company's operating results. In carrying out audit tasks, the Public Accounting Firm must comply with the Indonesian Public Accountant Code of Ethics as well as auditing standards known as ISA-based audits consisting of SA 200-299 regarding general principles and responsibilities, SA 300-499 regarding risk assessment and response to risk. ASA 500-599 regarding audit evidence, ISA 600-699 regarding the use of another party's work, ISA 700-799 regarding audit and reporting conclusions, and ISA 800-899 on special areas.

\section{Hypotheses}

\section{Time Budget Pressure and its effect on Audit Quality}

The pressure that the auditor experiences when conducting the audit due to the limited time allocated to carry out all audit tasks is called time budget pressure (De Zoort \& Lord, 1997). The auditor will feel that there is time pressure when carrying out the audit program due to the tight budget allocated for the audit time or an imbalance between the available audit time budget and the real-time requirements to complete the entire audit program (Kelley \& Seiler, 1982). When an auditor is under pressure due to the tight budget for audit time, the auditor's response may be functional and dysfunctional (De Zoort \& Lord, 1997).

Sososutikno (2003), states that time pressure is a condition that requires auditors to carry out predetermined time and budget efficiency because there are tight time and budget restrictions. Time budget pressure is an obstacle that arises because of the limited time and resources allocated to carry out tasks. Kelley et al. (1999); Prasita \& Adi (2007); and Kurnia (2018), in their research found that an auditor who works under time budget pressure is very dilemmatic and triggers a decline in audit quality. Furthermore, several other researchers disclosed the findings. the same, such as Dutadasanovan (2013); Muhsyi (2013); Gasperz (2014); Ningsih (2015).

Based on the conceptual description and the results of the empirical research above, it can be said that the time budget pressure faced by the audience in the audit creates a dilemma and can trigger dysfunctional behavior which can lead to a decrease in audit quality. Thus, the following research hypothesis can be developed:

H1: Time budget pressure has a negative effect on audit quality.

\section{Audit structure and how it moderates the effect of Time Budget Pressure on Audit Quality}

Audit structure is a systematic approach to auditing characterized by audit steps, logical sequence procedures, decisions, documentation, and using a comprehensive and integrated set of audit tools and policies to help auditors perform audits (Bowrin 1998). Muslim (2002), explains that the audit structure includes what must be done, instructions on how work must be completed, tools for coordination, tools for audit supervision and control, and tools for assessing the quality of work carried out. Understanding of a good audit structure can improve auditor performance. The use of an audit structure approach has advantages, namely encouraging effectiveness, encouraging efficiency, reducing litigation faced by KAP, having a positive impact on human resource consequences, and can facilitate service differentiation or quality so that it is thought to improve audit quality. Bamber et al. (1989), in their research, revealed that public accounting firms that use audit structures improve auditor performance, on the other hand, public accounting firms that do not use audit structures have the potential to increase role conflict and role ambiguity perceived by their audit staff. Likewise, research by Stuart \& Doughlas (2004) and Fanani et al. (2007), also confirmed the effect of the audit structure on audit quality. The conceptual description and empirical research results above indicate that if an auditor is equipped with an adequate audit structure in the form of a comprehensive and integrated audit guide, documentation, and a comprehensive and integrated set of audit tools and policies, he will be able to control the time budget pressures he is facing. can carry out the audit effectively and efficiently, and in the end, will be able to improve the quality of the audit. Thus, the following research hypothesis can be developed:

H2: The audit structure attenuates the negative effect time budget pressure has on audit quality. 
Auditor Independence and how it moderates the effect of Time Budget Pressure on Audit Quality

The backbone of the public accounting profession is independence. Aren et al. (2001), stated that the value of auditing is highly dependent on public perceptions of the independence of auditors. Independence is a mental attitude that is free from influence, not easily controlled by other parties, and independent of others. An auditor must be independent of external parties in examining the financial statements of the client company. Therefore, the absence of influence from external parties will influence internal parties to maintain auditor independence. Independence is the existence of honesty within the auditor to consider facts and objective and impartial considerations in formulating and expressing his opinion. Indonesian accountant's code of ethics article 1 paragraph 2 states that each member must maintain integrity, objectivity, and independence in carrying out their duties. The results of research conducted by Yulistiyani (2014) using a population of 40 respondents at Public Accounting Firms in Surakarta and Yogyakarta prove that there is a relationship between auditor independence and auditor performance where auditors who have high independence will not be easily influenced and are not easily controlled by parties. others in considering facts in the examination and in formulating and expressing their opinions so that their performance can be better. This is in line with research conducted by Nuraini (2017) and Ernawati \& Fitri (2017). The conceptual descriptions and empirical research results above indicate that if an auditor has strong independence will strive to develop an appropriate audit strategy, audit measures and communication are effective in overcoming time budget pressures without having to perform dysfunctional behavior, so that audit quality can be achieved. Thus, the following research hypothesis can be developed:

H3: Independence attenuates the negative effect time budget pressure has on audit quality.

\section{Audit supervision and how it moderates the effect of Time Budget Pressure on Audit Quality}

Supervision is one way that can be used to maintain audit quality and increase the efficiency of audit implementation (Georgiades, 2006). Supervision is a very important element in auditing because of the large amount of work that must be done by lower-level auditors (Arens et al., 2008). Most of the fieldwork is carried out by auditors at lower levels, therefore to ensure that the audits carried out meet the standards set, a supervision program is needed (Arens $e t$ al., 2008). The importance of the implementation of supervision in achieving quality audit implementation has also been stated by a professional body (Institut Akuntan Publik Indonesia). The conceptual description and empirical research results above show that if junior auditors or audit staff receive adequate audit supervision it will help them in dealing with audit complexities and/or time budget pressures and compliance pressures so that it will be able to help them carry out the audit properly. Thus, the following research hypothesis can be developed:

H4: Audit supervision attenuates the negative effect time budget pressure has on audit quality.

\section{Materials and Methods}

The specific objective of this study is to determine the ability of audit structures, independence, and audit supervision to moderate the effect of time budget pressure on audit quality. The sampling technique used was the purposive sampling technique. The data collection method used was a questionnaire survey method. The data analysis technique used in this study is the Moderated Regression Analysis (MRA) technique. Before the regression test is carried out, the instrument testing is carried out first, then followed by the classical assumption test which consists of the normality test, heteroscedasticity test, and multicollinearity. The results of the analysis are then interpreted and concluded.

\section{Results and Discussions}

\section{Descriptive Analysis}

Descriptive statistics in this study were conducted to provide information about the characteristics of research variables, namely: the minimum value or the smallest or lowest value of a data set, the maximum value is the largest or highest value of a data set. The average (mean) is the most common way to measure the central value of a data distribution under study. Standard deviation is a measure that shows the standard deviation of the observed data from the average data (Ghozali, 2017).

Jati , I. K., \& Suprasto , H. B. . (2020). Time budget pressure on audit quality with audit structure, independence, and audit supervision as moderating variable. International Research Journal of Management, IT and Social Sciences, 7(6). https://doi.org/10.21744/irjmis.v7n6.997 
Table 1

Statistic descriptive

\begin{tabular}{llllll}
\hline & $\mathrm{N}$ & Min. & Max. & Mean & Std. Deviation \\
\hline Time Budget Pressure (TEK) & 50 & 2.00 & 4.86 & 3.5824 & .75325 \\
Audit Structure (STR) & 50 & 3.40 & 5.00 & 4.0880 & .35722 \\
Independence (IND) & 50 & 3.17 & 4.83 & 4.0768 & .36753 \\
Audit Supervision (SUP) & 50 & 4.00 & 5.00 & 4.5508 & .23900 \\
Audit Quality (KUA) & 50 & 2.57 & 5.00 & 3.6658 & .61902 \\
Valid N (listwise) & 50 & & & & \\
\hline
\end{tabular}

\section{Hypothesis test}

Instrument testing with a pilot test was carried out before data collection. The pilot test was conducted by distributing questionnaires to 32 Masters of Accounting students at Udayana University. This is done to ensure that the instruments used in the study are valid and reliable. The results of the validity test show that the Pearson correlation, the respondents' statements of each research variable: time budget pressure (TEK), audit structure (STR), independence (IND), and audit quality (KUA) are greater than 0.30 or value. Sig. $=0.000$, which can be said that all respondents' statements in the questionnaire have met the valid requirements so that they are suitable for use in research. While the reliability test results show that all instruments for research variables: time budget pressure (TEK), audit structure (STR), independence (IND), and audit quality (KUA) have a Cronbach's Alpha coefficient greater than 0.70 so that it can be said to be reliable and feasible to be used in measuring research variables. This means that if the measurement is carried out more than once for the same symptom, the measurement will give consistent results.

Before doing multiple linear regression analysis, the regression model that is made must go through the classical assumption test first so that the resulting equation meets the BLUE (Best, Linear, Unbias, Estimator) rules. The results of the data normality test performed using the Kolmogorov-Smirnov method show that the coefficient value of Asymp.Sig. (2-tailed) is each greater than the alpha value of 0.05, namely: variable Time Budget Pressure $($ TEK) $=$ 0.167, Structure Audit $(\mathrm{STR})=0.062$, Independence $(\mathrm{IND})=0.096$, Audit Supervision $(\mathrm{SUP})=0.092$, and Audit Quality $(\mathrm{KUA})=0.178$ this means the data is normally distributed.

The multicollinearity test aims to test whether the regression model finds a correlation between independent variables (Ghozali, 2017). The multicollinearity test results show that all independent and moderating variables in this study are: Time Budget Pressure (TEK), Audit Structure (STR), Independence (IND), Audit Supervision (SUP), and Audit Quality (KUA) variables greater than 0.10 and VIF less than 10, which indicates that there is no symptom (free) multicollinearity between the independent variables.

The heteroscedasticity test aims to test whether in the regression model there is an inequality of variants from the residuals of one observation to another. The results of the heteroscedasticity test show that all independent variables in this study, namely the use of information technology, the relevance of information technology, the satisfaction of accounting information systems, the effectiveness of accounting information systems show sig value each of 0.869 ; $0.232 ; 0.822$; and $0.236>0.05$. This means that there is no influence between the independent variables on absolute residuals, so the regression model used does not contain heteroscedasticity symptoms.

After the classical assumption test is carried out, the following is described in succession: the results of the model feasibility test ( $F$ test), the coefficient of determination (R2), and the research hypothesis test ( $\mathrm{t}$-test) based on the information presented in Table 2.

Based on the F test presented in Table 2 it can be seen that the Sig. The F test is 0.000 which means that this MRA model meets the model's feasibility test so that it can be used in the MRA test. Furthermore, it is also known that the coefficient of determination (R2) is 0.923 , which means that the independent and moderating variables in the model can explain the variation of the dependent variable KUA by $92.3 \%$ while the remaining $7.7 \%$ is explained by other variables outside the model.

Based on the results of the MRA test as presented in Table 2, it can be seen that the constant value is 7,781, which means that without the TEK, STR, IND, and SUP variables as well as the interaction variables TEK.STR, TEK.IND, and TEK.SUP, KAP auditors in Bali are relatively still conducting quality audits, for example, may be due to other variables such as audit competence, audit experience, professional skepticism, and so on. 
Table 2

Result of Model Feasibility Test (F Test), Coefficient of Determination (R2), And Research Hypothesis Test (t-test)

\begin{tabular}{llrrr}
\hline \multirow{2}{*}{ Model } & \multicolumn{2}{c}{ Unstandardized Coefficients } & Standardized Coefficients & \multirow{2}{*}{ Sig. } \\
\cline { 2 - 3 } & \multicolumn{1}{c}{$\mathrm{B}$} & Std. Error & Beta & \\
\hline 1 (Constant) & 7.781 & 1.976 & 3.938 .000 \\
Time Budget Pressure (TEK) & -.030 & .035 & -.047 & -.865 .391 \\
Audit Structure (STR) & .492 & .113 & .323 & 4.347 .000 \\
Independence (IND) & .270 & .082 & .3323 .282 .002 \\
Audit Supervision (SUP) & .143 & .043 & .3943 .331 .002 \\
TEK.STR & .016 & .105 & 1.6042 .966 .005 \\
TEK.IND & .026 & .010 & 1.3782 .530 .015 \\
TEK.SUP & .019 & .016 & 1.5162 .628 .011 \\
\hline
\end{tabular}

Model Feasibility Test Results with Sig. F $\quad 0,000$

Value of the coefficient of determination $\left(\mathrm{R}^{2}\right) \quad 0,923$

a. Dependent Variable: Audit Quality (KUA)

Based on Table 2. it can be seen that the results of the hypothesis test (t-test) of the effect of the TEK variable on KUA obtained the Sig. of 0.391 with an unstandardized coefficients beta value of -0.030 , which means that time budget pressure (TEK) has a negative but insignificant effect on audit quality (KUA) or in other words, the increasing perceived time budget pressure by KAP auditors in Bali is decreasing quality. KAP audits in Bali but this decline is not significant. The results of this test reject the H1 hypothesis which states that time budget pressure (TEK) has a negative and significant effect on audit quality (KUA).

The partial test results of the effect of the audit structure on audit quality can be seen that the Sig. of 0.000 with a beta unstandardized coefficients value of 0.492 which means that the audit structure has a significant positive effect on audit quality. Based on Table 2 it can be seen that the Sig value. TEK.STR variable is 0.005 with an unstandardized coefficients beta value of 0.016 which means that the audit structure (STR) can weaken the negative effect of time budget pressure (TEK) on audit quality (KUA). Thus, the results of this test accept the H2 hypothesis, or in other words, the better the audit structure will be able to support auditors in anticipating a decrease in audit quality (KUA) due to increased time budget pressure (TEK).

The results of the partial test of the effect of independence on audit quality inform the Sig. of 0.002 with a beta unstandardized coefficients value of 0.270 , which means that independence has a significant positive effect on audit quality. Or, in other words, the more auditors can maintain independence in the field audit process, in particular, it will improve audit quality (KUA). Based on Table 2 it can also be seen that the Sig value. TEK.IND variable is 0.015 with an unstandardized coefficients beta value of 0.026 which means that independence (IND) can weaken the negative effect of time budget pressure (TEK) on audit quality (KUA) or in other words the stronger the auditor independence in the audit process, The more able to anticipate a decrease in audit quality (KUA) due to increased time budget pressure (TEK). Thus, the results of this test accept the H3 hypothesis which says that independence weakens the negative effect of time budget pressure on audit quality.

The partial test results of the effect of audit supervision on audit quality can be seen that the Sig. of 0.002 with a beta unstandardized coefficients value of 0.143 which means that the audit structure has a significant positive effect on audit quality. Based on Table 2 it can be seen that the Sig value. TEK.SUP variable is 0.005 with an unstandardized coefficients beta value of 0.016 which means that audit supervision (SUP) can weaken the negative effect of time budget pressure (TEK) on audit quality (KUA). Thus, the results of this test accept the hypothesis H4 which states that audit supervision (SUP) weakens the negative effect of time budget pressure (TEK) on audit quality (KUA) or in other words the better audit supervision by senior auditors and / or audit managers will be able to encourage efforts to anticipate a decrease in audit quality (KUA) due to increased pressure on time budgets (TEK).

Jati , I. K., \& Suprasto , H. B. . (2020). Time budget pressure on audit quality with audit structure, independence, and audit supervision as moderating variable. International Research Journal of Management, IT and Social Sciences, 7(6). https://doi.org/10.21744/irjmis.v7n6.997 
Discussion

Time budget pressure has a negative effect on audit quality

The results of hypothesis $\mathrm{H} 1$ testing indicate that time budget pressure has a negative and insignificant effect on audit quality. This means that time budget pressure is not strong enough to influence the quality of their audits. This is probably because KAP auditors in Bali feel that time budget pressure is not too high based on the mean value of respondents' responses to the descriptive statistical data in Table 1, which is only 3.5824 from the maximum value on a scale of 5. The results of this study are in line with the research of Eka \& Devi (2016) who found time budget pressure had a negative and insignificant effect on the audit quality of KAP in Bandung City. The same result was also achieved by Utami \& Sirajuddin (2013) who found that time pressure had no significant negative effect on KAP audit quality in Palembang City. On the other hand, several other researchers found different results. Prasita \& Adi (2007), found that time budget pressure has a negative and significant effect on audit quality. These results are in line with the research of Ningsih (2015); Kurnia (2009); Dutadasanovan (2013); and Muhshyi (2013). The results of this study are also different from the results of research conducted by Jelista (2015); Arisinta (2013); Hapsari (2016), and Aprianto (2015), which state that time budget pressure has a positive and significant effect on audit quality. Kelley et al., (1999); Prasita \& Adi (2007); and Kurnia (2009), in their research found that an auditor who works under time budget pressure is very dilemmatic and triggers a decline in audit quality. Furthermore, several other researchers disclosed the findings. the same, such as Dutadasanovan (2013); Muhsyi (2013); Gasperz (2014); Ningsih (2015).

The audit structure attenuates the negative effect time budget pressure has on audit quality

The results of this research found that the audit structure partially has a positive effect on audit quality. These results are consistent with research conducted by Bamber et al. (1989), who revealed that public accounting firms that use audit structures improve auditor performance, on the other hand, public accounting firms that do not use audit structures have the potential to increase role conflict and role ambiguity perceived by their audit staff. Likewise, research by Stuart \& Doughlas (2004) and Fanani et al. (2007), also confirms the effect of the audit structure on audit quality. Furthermore, this research also confirms the ability of audit structures to weaken the negative effect of time budget pressure on audit quality. This means that the decline in audit quality as a result of increasing time budget pressures can be controlled by improving the quality of the audit structure. According to the respondent's response, several things play a major role, namely: 1) compliance with the established audit programs and policies, 2) adequate audit tools, and comprehensive and integrated complaint policies. Besides, it is necessary to pay attention to the maximum role of this audit structure, especially the need for more detailed technical procedures and instructions.

\section{Independence (IND) attenuates the negative impact time budget pressure (TEK) on audit quality (KUA)}

The results of this research found that partially independence has a positive effect on audit quality, meaning that the more independent the auditor is in carrying out the audit process, the higher the audit quality. These results are by research conducted by Yulistiyani (2014); Nuraini (2017); and Ernawati \& Fitri (2017).

Furthermore, this research also found that independence attenuates the negative effect of time budget pressure on audit quality. This means that if auditors in the audit process can always maintain their independence by the code of ethics for Indonesian accountants article 1 paragraph 2, they will be able to reduce the impact of the decline in audit quality due to time budget pressures. Based on the respondent's response, it can be seen that two (2) components of independence that support him the most in situations of time budget pressure, namely: 1) free from personal interests or relationships that limit examination, and 2) freedom in direct examination and free access to all books. books, records, company officers, and employees as well as other sources of information relating to business activities, obligations, and resources. Meanwhile, what is most felt to be improved is related to independence is related to freedom in implementing audit procedures and freedom from feeling not to modify the effect of reported facts on certain parties. Furthermore, through the exposure to the results of the partial effect of independence and the ability of independence to weaken the negative effect of time budget pressure on audit quality, it can be seen that: 1) independence has a significant positive effect on audit quality, and 2) at the same time independence weakens the negative effect of time budget pressure on audit quality. audit quality, thus, 3) based on the classification criteria for the type of moderating variable emphasized by Ghozali (2016), the independent variable is a type of quasi moderating variable. Audit supervision (SUP) weakens the negative effect of time budget pressure (TEK) on audit quality (KUA) 
As previously described, partially audit supervision has a positive effect on audit quality, meaning that a competent auditor who is supported by adequate supervision will improve audit quality. The results are by research conducted by Gupta et al. (1999); Meier \& Fuglister (1992). Furthermore, it is also known that audit supervision weakens the negative effect of time budget pressure on audit quality. This means that auditors will be able to control the impact of time budget pressure on the decline in audit quality if they are supported by adequate audit supervision by 1) the first field audit standard states that work must be well planned and if used assistants must be properly supervised, and 2) audit standards section 311 which states that supervision includes the direction of the assistant's business related to the achievement of audit objectives and determining whether these objectives are achieved (SPAP, 2016). The most felt audit supervision helped the auditor (respondent) in controlling time budget pressures, namely: 1) honest, open, and interactive feedback on my performance provided by the supervisor, 2) the supervisor explains the overall assignment, and 3) Supervisors supervise until the job is finished. Meanwhile, supervision that still needs to be improved are 1) fairness in distributing opportunities and workloads, and 2) the role of supervisors in developing communication, critical thinking, and analytical skills.

Based on the description above, it can be seen that the results of the partial effect test of audit supervision and the ability of audit supervision to moderate the effect of time budget pressure on audit quality can be seen that: 1) audit supervision has a significant positive effect on audit quality, and 2) at the same time audit supervision weakens the influence negative time budget pressure on audit quality, so 3) based on the classification criteria for the moderating variable type emphasized by Ghozali (2016), the audit supervision variable is a type of quasi moderating variable.

\title{
4 Conclusion
}

Based on hypothesis testing and discussion of the research results as previously described, it can be concluded as follows: time budget pressure has no significant negative effect on audit quality, the audit structure attenuates the negative effect of time budget pressure on audit quality, independence attenuates the negative influence of time budget pressure on audit quality, audit supervision attenuates the negative effect of time budget pressure on audit quality

\section{Conflict of interest statement}

The authors declared that they have no competing interests.

\section{Statement of authorship}

The authors have a responsibility for the conception and design of the study. The authors have approved the final article.

\section{Acknowledgments}

We are grateful to two anonymous reviewers for their valuable comments on the earlier version of this paper.

\author{
Jati , I. K., \& Suprasto , H. B. . (2020). Time budget pressure on audit quality with audit structure, independence, \\ and audit supervision as moderating variable. International Research Journal of Management, \\ IT and Social Sciences, 7(6). https://doi.org/10.21744/irjmis.v7n6.997
}




\section{References}

Alim, M. N., Hapsari, T., \& Purwanti, L. (2007). Pengaruh Kompetensi dan Independensi terhadap Kualitas Audit dengan Etika Auditor sebagai Variabel Moderasi. SNA X Makassar.

Aprianto, D. (20105). Pengaruh Independensi, Pengalaman, Due Professional Care, Akuntabilitas Dan Time Budget Pressure Terhadap Kualitas Audit.

Aren, A. A., Randal J. E., \& Mark S. B. (2001). Auditing dan Pelayanan Verifikasi. Jakarta: Indeks.

Arens, A. A., \& Loebbecke, J. L. (2008). Auditing Pendekatan Terpadu, Terjemahan oleh Amir Abadi Yusuf. Edisi Kedua. Jakarta: Salemba Empat.

Arisinta, O. (2013). Pengaruh Kompetensi, Independensi, Time Budget Pressure, dan Audit Fee Terhadap Kualitas Audit Pada Kantor Akuntan Publik di Surabaya. Jurnal Ekonomi dan Bisnis Airlangga (JEBA)| Journal of Economics and Business Airlangga, 23(3).

Azad, A. N. (1994). Time budget pressure and filtering of time practices in internal auditing. Managerial Auditing Journal.

Bamber, E. M., Snowball, D., \& Tubbs, R. M. (1989). Audit structure and its relation to role conflict and role ambiguity: An empirical investigation. Accounting review, 285-299.

Basuki, B., \& Mahardani, K. Y. (2006). Pengaruh tekanan anggaran waktu terhadap perilaku disfungsional auditor dan kualitas audit pada kantor akuntan publik di Surabaya. Jurnal Manajemen, Akuntansi \& Sistem Informasi, 6(2), 203-223.

Bowrin, A. R. (1998). Review and synthesis of audit structure literature. Journal of Accounting literature, 17, 40.

Braun, R. L. (2000). The effect of time pressure on auditor attention to qualitative aspects of misstatements indicative of potential fraudulent financial reporting. Accounting, Organizations and Society, 25(3), $243-259$. https://doi.org/10.1016/S0361-3682(99)00044-6

Christiawan, Y. J. (2002). Kompetensi dan independensi akuntan publik: refleksi hasil penelitian empiris. Jurnal Akuntansi dan Keuangan, 4(2), 79-92.

DeZoort, F. T. (1998). Time pressure research in auditing: Implications for practice. The Auditor's Report, 22(1), 1112.

DeZoort, F. T., \& Lord, A. T. (1997). A review and synthesis of pressure effects research in accounting. Journal of accounting literature, 16, 28.

Djalil, M. A. (2002). Persepsi Auditor Tentang Pengaruh Struktur Audit dan Prinsip Organisasional Terhadap Konflik dan Ambiguitas Peran. Lembaga Penelitian Universitas Syah Kuala, 5, 146-162.

Dutadasanovan, Y. (2013). Pengaruh Time Budget Pressure Terhadap Kualitas Audit Dengan Independensi Sebagai Variabel Intervening (Studi Kasus Pada BPK RI Perwakilan Provinsi Jawa Tengah) (Doctoral dissertation, Universitas Negeri Semarang).

Eriani, E. (2010). Pengaruh Struktur Audit, Konflik Peran, dan Ketidakjelasan Peran Terhadap Kinerja Auditor (Studi Pada KAP di Sumatera Barat). Skripsi Fakultas Ekonomi Universitas Andalas.

Ernawati, P. S., \& Fitri, L. W. (2017). Pengaruh Independensi, Etika Profesi, Profesionalisme, Dan Komitmen Organisasi Terhadap Kinerja Auditor (Studi Empiris pada KAP di Kota Surakarta dan Yogyakarta) (Doctoral dissertation, IAIN Surakarta).

Fanani, Z., Hanif, R. A., \& Subroto, B. (2008). Pengaruh struktur audit, konflik peran, dan ketidakjelasan peran terhadap kinerja auditor. Jurnal Akuntansi dan Keuangan Indonesia, 5(2), 139-155.

Fisher, J. G. (1998). Contingency theory, management control systems and firm outcomes: past results and future directions. Behavioral research in accounting, 10, 47.

Gasperz, J. (2014). Pengaruh Tekanan Anggaran Waktu Sebagai Variabel Moderasi terhadap Hubungan antara Faktor Individu dan Kualitas Audit. Dinamika Akuntansi Keuangan Dan Perbankan, 3(1).

Gayatri, K. D. P., \& Suputra, I. D. (2016). Pengaruh Struktur Audit, Tekanan Waktu, Disiplin Kerja dan Komitmen Organisasi pada Kinerja Auditor. E-Jurnal Akuntansi Universitas Udayana, Mei (15), 1366-1391.

Georgiades, G. (2006). Audit procedures. CCH.

Ghozali, I. (2016). Aplikasi Analisis Multivariete IBM SPSS 23, Badan Penerbit Universitas Diponegoro, Semarang. 2016. Aplikasi analisis multivariate dengan program IBM SPSS, 23.

Ghozali, I. (2017). Econometrics Theory, Concepts, and Applications with SPSS 17. Semarang: Diponegoro University Publishing Agency.

Govindarajan, V. (1986). Impact of participation in the budgetary process on managerial attitudes and performance: Universalistic and contingency perspectives. Decision sciences, 17(4), 496-516. 
Gul, F. A., Kim, J. B., \& Qiu, A. A. (2010). Ownership concentration, foreign shareholding, audit quality, and stock price synchronicity: Evidence from China. Journal of financial economics, 95(3), 425-442. https://doi.org/10.1016/j.jfineco.2009.11.005

Gupta, P. P., Umanath, N. S., \& Dirsmith, M. W. (1999). Supervision practices and audit effectiveness: an empirical analysis of GAO audits. Behavioral Research in Accounting, 11, 27.

Hanif, R. A. (2013). Pengaruh Struktur Audit, Konflik Peran, dan Ketidakjelasan Peran Terhadap Kinerja Auditor, Jurnal Ekonomi, Vol. 21, No. 3 September.

Hapsari, R. E. (2016). Pengaruh Independensi, Time Budget Pressure, Skeptisisme Profesional Auditor, Etika Auditor Dan Pengalaman Kerja Auditor Terhadap Kualitas Hasil Pemeriksaan Auditor Pemerintah Daerah (Survai Pada Inspektorat Kota/Kabupaten Se-Eks Karesidenan Surakarta) (Doctoral dissertation, Universitas Muhammadiyah Surakarta).

Hartanto, H. Y. (2001). Analisis Pengaruh Tekanan Ketaatan Terhadap Judgment Auditor (Doctoral dissertation, [Yogyakarta]: Universitas Gadjah Mada).

Herawaty, S. A. (2007). Analisis pengaruh independensi, mekanisme corporate governance, dan kualitas audit terhadap integritas laporan keuangan. Makalah Simposium Nasional Akuntansi X, Makassar.

Herrbach, O. (2001). Audit quality, auditor behaviour and the psychological contract. European Accounting Review, 10(4), 787-802.

Huda, M. (2000). Hubungan Antara Tindakan Supervisi Dengan Kepuasan Kerja. Jurnal Bisnis dan Akuntansi, 2(1), 33-44.

Institut Akuntan Publik Indonesia (2016). Standar Profesional Akuntan Publik. Jakarta :Penerbit Salemba Empat.

Jelista, M. (2015). Pengaruh Kompleksitas Audit. Tekanan Anggaran Waktu, Dan Pengalaman Auditor Terhadap Kualitas Audit, 2(2), 1-15.

Jensen, M. C., \& Meckling, W. H. (1976). Theory of the firm: Managerial behavior, agency costs and ownership structure. Journal of financial economics, 3(4), 305-360. https://doi.org/10.1016/0304-405X(76)90026-X

Kelley, T., \& Seller, R. E. (1982). Auditor stress and time budgets. The CPA Journal (pre-1986), 52(000012), 24.

Kelly, T., Margheim, L., \& Pattison, D. (1999). Survey on the differential effects of time deadline pressure versus time budget pressure on auditor behavior. Journal of Applied Business Research (JABR), 15(4), 117-128.

Kirana, I. G. A. M. I., \& Ramantha, I. W. (2020). The effect of auditor rotation, time pressure, and audit tenure on audit quality with auditor specialization as moderation variable. International research journal of management, IT and social sciences, 7(3), 126-136.

Kurnia, K. (2018). Pengaruh Tekanan Waktu Audit Dan Locus Of Control Terhadap Tindakan Yang Menurunkan Kualitas Audit. EKUITAS (Jurnal Ekonomi dan Keuangan), 15(4), 456-476.

Kurnia, W., Khomsiyah, K., \& Sofie, S. (2014). Pengaruh Kompetensi, Independensi, Tekanan Waktu, dan Etika Auditor terhadap Kualitas Audit. Jurnal Akuntansi Trisakti, 1(2), 49-67.

Lowensohn, S., Johnson, L. E., Elder, R. J., \& Davies, S. P. (2007). Auditor specialization, perceived audit quality, and audit fees in the local government audit market. Journal of Accounting and Public Policy, $26(6), 705-732$. https://doi.org/10.1016/j.jaccpubpol.2007.10.004

Meier, H. H., \& Fuglister, J. (1992). How to improve audit quality: Perceptions of auditors and clients. The Ohio CPA Journal, 6, 21-24.

Messier, W. F., Glover, S. M., \& Prawitt, D. F. (2014). Jasa audit dan assurance: pendekatan sistematis. Jakarta: Salemba Empat.

Mindarti, C. S. (2015). Pengaruh karakteristik individu terhadap kinerja auditor. Jurnal Ekonomi dan Bisnis, 18(3), 59-74.

Muhshyi, A. (2013). Pengaruh Time Budget Pressure, Risiko Kesalahan dan Kompleksitas terhadap Kualitas Audit.

Mulyadi. (2008). Sistem Akuntansi. Cetakan Keempat. Jakarta : Salemba Empat.

Murray, D. (1990). The performance effects of participative budgeting: An integration of intervening and moderating variables. Behavioral Research in accounting, 2(2), 104-123.

Ningsih, S. (2015). Pengaruh Kompetensi, Independensi dan Jenis Kelamin Auditor Terhadap Kualitas Audit dengan Kecerdasan Emosional Sebagai Variabel Moderasi: Studi Empiris pada Kantor Akuntan Publik di Malang.

Nuraini, L. (2017). Pengaruh independensi, gaya kepemimpinan, dan budaya organisasi terhadap kinerja auditor (studi empiris pada kantor akuntan publik Yogyakarta dan Solo). Jurnal Profita: Kajian Ilmu Akuntansi, 5(2).

Outley, D. (1991). Management Control, Organizational Desaign and Accounting Information System.

Prasita, A., \& Adi, P. H. (2007). Pengaruh kompleksitas audit dan tekanan anggaran waktu terhadap kualitas audit dengan moderasi pemahaman terhadap sistem informasi. Jurnal Ekonomi dan Bisnis, 13(1), 54-78.

Jati , I. K., \& Suprasto , H. B. . (2020). Time budget pressure on audit quality with audit structure, independence, and audit supervision as moderating variable. International Research Journal of Management, IT and Social Sciences, 7(6). https://doi.org/10.21744/irjmis.v7n6.997 
Putra, I. G. B. W., Wira, G. B., \& Ariyanto, D. (2012). Pengaruh Independensi, Profesionalisme, Struktur Audit, dan Role Stress Terhadap Kinerja Auditor BPK RI Perwakilan Provinsi Bali. E-Jurnal Akuntansi, 1(1), 1-18.

Putri, S. W. (2013). Pengaruh Kompetensi, Independensi Dan Pengalaman Terhadap Kualitas Audit (Studi Pada Kantor Akuntan Publik di Yogyakarta dan Surakarta) (Doctoral dissertation, Universitas Muhammadiyah Surakarta).

Seni, F., D. (2012). Pengaruh Tekanan Ketaatan, Kompleksitas Tugas, Pengetahuan dan Persepsi Etis terhadap Audit Judgement. Dipongoro Journal of Accounting 1(1), 1-12

Sososutiksno, C. (2003). Hubungan tekanan anggaran waktu dengan perilaku disfungsional serta pengaruhnya terhadap kualitas audit (Doctoral dissertation, [Yogyakarta]: Universitas Gadjah Mada).

Stuart, I., \& Prawitt, D. F. (2004). The influence of audit structure on auditors' performance in high and low complexity task settings. Available at SSRN 569871.

Tunggal, A. W. (2000). Auditing Suatu Pengantar. Jakarta: Penerbit Rineka Cipta.

Utami, R., \& Sirajuddin, B. (2013). Pengaruh Ukuran Kantor Akuntan Publik (KAP), Masa Perikatan Dan Tekanan Waktu Terhadap Kualitas Audit. Jurusan Akuntansi S, 1 .

Willett, C., \& Page, M. (1996). A survey of time budget pressure and irregular auditing practices among newly qualified UK chartered accountants. The British Accounting Review, 28(2), 101-120. https://doi.org/10.1006/bare.1996.0009

Yulistiyani, N. (2014). Pengaruh Independensi Auditor, Gaya Kepemimpinan, Komitmen Organisasi Dan Budaya Organisasi Terhadap Kinerja Auditor (Studi Empiris Pada Kantor Akuntan Publik Di Surakarta Dan Yogyakarta) (Doctoral dissertation, Universitas Muhammadiyah Surakarta). 